\title{
Projects portfolio determination based on key stakeholders' expectations and requirements: Evidence from public university projects
}

\author{
Mohsen Cheshmberah ${ }^{a^{*}}$
}

${ }^{a}$ Faculty of Management \& Industrial Engineering, Malek Ashtar University of Technology, Iran

\begin{tabular}{l}
\hline C H R O N I C L E \\
\hline Article history: \\
Received: September 22019 \\
Received in revised format: Sep- \\
tember 2019 \\
Accepted: October 22019 \\
Available online: \\
October 2 2019 \\
\hline Keywords: \\
Stakeholders analysis \\
Stakeholder identifying \\
Power/Interest matrix \\
Public university \\
Project portfolio management \\
Mathematical model
\end{tabular}

\section{A B S T R A C T}

\begin{abstract}
Project stakeholder management deals with managing and fulfilling stakeholder expectations and has tended to focus on the stakeholders of the organization or the project viewpoint. The thematic, spatial and temporal objects of the research were to analyze the stakeholders and projects portfolio determination based on key stakeholders of a public university in Iran in 2019. In first step, stakeholders are identified. There are 12 stakeholder groups involved the university under study. In the second step using the power/interest matrix, stakeholder categorization and positioning was performed. In the following, a mathematical model for optimizing the portfolio of projects was presented and solved. This model was developed to maximize college profit while simultaneously considering the expectations and the requirements of four key stakeholders - the board of trustees, faculty members, researchers and the Ministry of Science. These findings may mainly reflect the strategic decisions at the university.
\end{abstract}

\section{Introduction}

Stakeholder theory is one of the organization management theories. The concept of stakeholder was first presented by the Stanford Research Institute in 1936. Freeman can be mentioned as the founder of stakeholder analysis who incorporated this issue into the strategic management literature. In 1984, he presented an article in which he proposed the model and importance of stakeholder analysis in strategic management (Freeman, 1984 (First Published by Pitman)- 2010 (Digital Version by Cambridge University Press)). Interest in stakeholders has grown considerably since Freeman's (1984) work was published. The interactions with stakeholders and interrelationships between them largely influence the overall performance of organizations and the results of the projects (Kumar, 2015). While stakeholder analysis is rooted in business management, it has spread to other areas such as economics, political science, game theory, and the environmental sciences; common stakeholder analysis models use a wide range of qualitative and quantitative tools to identify stakeholders, their position, their impact on each other, and their interests. From one perspective, stakeholders include any individual or group that has been influenced by organizational activities or is likely 
to be affected by organizational activities. Traditionally, stakeholders are any individual or group that is influenced by or influences an organization in achieving its goals (Freeman, 1984 (First Published by Pitman)- 2010 (Digital Version by Cambridge University Press)). Stakeholder management is one of the most important issues in organizations and projects. Since stakeholders may consist of people with specific, even conflicting interests, backgrounds, and skills, they need interaction and coordination throughout the project life to achieve the organization's goals and become successful. Due to the complex environmental conditions of organizations, stakeholder management creates effective interactions between the stakeholders of the organization or project by balancing different and sometimes conflicting requirements. According to Kroll's definition, stakeholder management process includes gathering stakeholder information and identification, use of stakeholder information to predict their behavior, determine how to manage their position, to direct conditions and effective factors to achieve the project/organization goal(s). Some researchers believe that the stakeholders are those who use the system directly or indirectly, or those who are involved in system development (Sharp, Finkelstein, \& Galal, 1999). Project stakeholder management deals with managing and fulfilling stakeholder expectations and has tended to focus on the stakeholders of the organization or the project viewpoint. The stakeholders' impact - both public and private actors- is important because they can significantly influence projects and organizations (Beringer et al., 2013).

\section{The problem statement}

Stakeholders may be affected by projects or project outcomes; thus, they must not be ignored in project management, which is reflected in some definitions of project success. Project portfolio stakeholders is defined as any group or individual in a relationship with a project portfolio, such that the group or individual can affect or is affected by the achievement of the portfolio's objectives (Beringer et al., 2013). The focus of this article is to study the stakeholders of a public university. A public university is a university that is in state ownership or receives significant public funds through a national or subnational government, as opposed to a private university (Public university, 2019). At the university, the university's board of trustees asked the college managers to cover part of their expenses. To accomplish this goal, the college managers have focused on earning and forming an effective portfolio of projects. The portfolio of projects consists of educational and research activities and projects. The types of projects and activities the colleges can do are as follows:

- Research projects that are owned by companies outside the university

- Admitting students and converting them to graduates

- Implementing on the job training (OJT) and Knowledge and skill increasing courses for applicants (such as managers) in the form of short-term project projects

Naturally, these projects have both revenue and cost; therefore, the maximum profit should be considered. Another important point is that the college managers must consider the constraints and expectations of other stakeholders in order to form an annual portfolio of their projects, in addition to expecting the university trustees as a stakeholder. Accordingly, the aim is to determine the effective number of research projects, the number of students admitted annually, and the number of short-term courses given the constraints and expectations of (key) stakeholders simultaneously. In this paper, in addition to an overview of the stakeholders' management background in the universities as well as the impact of the stakeholders in the portfolio of the projects, the stakeholders of the university are studied, identified and categorized, and then a mathematical model for optimizing the portfolio of projects is presented and solved.

\section{Theoretical background}

\subsection{Stakeholder analysis in higher education centers and universities}

Stakeholder management for higher education centers and universities is a topic which has gained less attention. Here is a look at some of the references that have specifically addressed stakeholder analysis of academic centers. 
Chapleo and Simms (2010) analyzed university stakeholders by studying a case study at Portsmouth University, England. In this study, 30 university stakeholders were identified and among these 30 groups, 12 were classified as being of particular importance (Chapleo \& Sims, 2010). Mainardes et al. (2013) performed a case study on a Portuguese state university to identify, classify and rank the stakeholders of a university and also, to qualify the importance of the stakeholders (Mainardes, Alves, \& Raposo, 2013). Matkovic et al. (2014) introduced a model of the analysis phase of the curriculum development process for identifying and selecting key curriculum stakeholders. In this research, external stakeholders, their roles and contribution, and related process have been analyzed (Matkovic, Tumbas, Sakal, \& Pavlićević, 2014). Kettunen (2014) has developed a stakeholder mapping concept for universities and higher education institutions. The stakeholder map shows the extent of their involvement in improvement and their impact. In this study, stakeholders are categorized by the Balanced Scorecard approach and are categorized according to the four perspectives of financial, processes, external impacts and growth and learning (Kettunen, 2014). Fleaca et al. (2017) examined the relationship between stakeholders and entrepreneurship enhancement in higher education institutions. Training in university, especially in the field of engineering, needs to teach special skills to students. In this study, the SIPOC (Supplier, Input, Process, Output, Customers) model has been used for better analysis (Fleaca, Fleaca, \& Maiduc, 2017). Hujainah et al. (2017) examined stakeholder qualification and prioritization (SQP) in a review study. In this paper, 31 out of 210 articles known as preliminary studies were reviewed. The results showed that prioritization and qualification of stakeholders is critical to the performance of a system because it helps to identify stakeholders more accurately and also to prioritize their needs. In addition, 17 stakeholder characteristics were obtained. Also, 9 techniques are presented in this paper for stakeholder qualification and prioritization (Hujainah, Abu Bakar, Al-Haimi, \& Abdulgabber, 2017). Tran (2018) analyzed stakeholders on the skills gap of Vietnamese students. The purpose of this study was to investigate the skills gap causes of students, especially engineering students, and to figure which stakeholders were responsible for this gap. For this purpose, he interviewed 38 well-known stakeholders via email and interviewed 475 students, graduates and faculty members. The results of this study showed that the most important reasons are non-dynamic curriculum planning, labor market changes, limited university facilities and low-effort students. The researcher suggests that instead of stakeholders looking for the guilty party while blaming each other, they can address this issue by working together with persistent surveys, as well as committing students to greater learning skills and updating training material and methods (Tran, 2018). Table 1 summarizes the reviewed research.

\subsection{Stakeholders impact in project portfolio management}

Project portfolios have been defined as a set of projects that are conducted under the management of an organization and that compete for scarce resources. Stakeholder management is key success factors within project portfolio management (PPM) (Beringer, Jonas, \& Kock., 2013). Chual et al. (2011) examined evolution of the control portfolio in a multi-stakeholder project. They believed that the corporate headquarters (the project's principal controller) must simultaneously ensure that the various stakeholders are aligned with the project's goals despite, and that the stakeholders collaborate with each other to achieve project success (Soh, Chua, \& Singh, 2011). Beringer et al. (2013) studied the effect of portfolio-internal stakeholders on project portfolio success. They examined the relationship between the intensity of engagement (IoE) of stakeholders and portfolio success (Beringer, Jonas, \& Kock., 2013). Davis (2014) examined background the project success. He investigated stakeholders involved in projects and showed a lack of agreement in perceptions of project success factors between stakeholders as an important obstacle to project success (Davis, 2014). Bahadorestani et al. (2018) offered a framework to identify project stakeholders and to determine the expectations of key stakeholders. They designed the expectations' model using the QFD approach (Bahadorestani, Ghalehnovi, \& Motahari Farimani, Designing a Model of key Stakeholders' Expectations in the Subway Construction Projects: Studied in MUR Construction Project, 2018). 
Vuorinen and Martinsuo (2018) studied the influence of stakeholders on projects through their expectation of project value. They considered the value-oriented reasons for stakeholders to utilize influence strategies (Vuorinen \& Martinsuo, 2018). Derakhshan et al. (2019) reviewed project governance literature to extract roles of stakeholders and relationships inside and outside of the organization (Derakhshan, Turner, \& Mancini, 2019). Bahadorestani et al. (2019) provided a framework to elevate effectiveness of the stakeholder engagement in projects by ranking the potential conflicts of stakeholders and project management team (Bahadorestani, Naderpajouh, \& Sadiq, Planning for sustainable stakeholder engagement based on the assessment of conflicting interests in projects , 2019). Yu et al. (2019) proposed a model for analyzing stakeholder conflicts in urban redevelopment projects based on the stakeholder salience theory and Pawlak's conflict theory (Yu, Liang, Shen, Shi, \& Wang, 2019). Baqeria et al. (2019) proposed a multi-objective model for selecting the project portfolio that maximizes efficiency and quality and minimizes the risk in project execution (Baqeria, Mohammadia, \& Mofrad Gilania, 2019).

\section{Table 1}

Summary of research reviewed

Stakeholder analysis in universities Author Description

Chapleo and Simms (2010) (Chapleo Identification, classification and analysis of stakeholders in Portsmouth University,

\& Sims, 2010) UK

Mainardes et al. (2013) (Mainardes,

Alves, \& Raposo, 2013)

identifying, classifying and ranking the stakeholders of a university in Portugal

Matkovic et al. (2014) (Matkovic,

Tumbas, Sakal, \& Pavlićević, 2014)

analysis of the curriculum development process and identifying and selecting key curriculum stakeholders

Kettunen (2014) (Kettunen, 2014)

Developing a conceptual map for educational institution stakeholders and use of balanced scorecard

Fleaca et al. (2017) (Fleaca, Fleaca, \& Investigating the relationship between stakeholders and entrepreneurship enhanceMaiduc, 2017)

Hujainah et al. (2017) (Hujainah, Abu

Bakar, Al-Haimi, \& Abdulgabber, 2017)

Tran (2018) (Tran, 2018) ment in higher education Institutions

Evaluation of stakeholder prioritization and qualification methods

Investigating the reasons for students' skills gap with market needs and its relationship to academic stakeholders

Stakeholders impact in PPM

Author

Description

Chual et al. (2011) (Soh, Chua, \& the control portfolio in a multi-stakeholder project

Singh, 2011)

Beringer et al. (2013) (Beringer, Jonas,

\& Kock., 2013)

Davis (2014) (Davis, 2014)

Bahadorestani et al. (2018)

(Bahadorestani, Ghalehnovi, \&

Motahari Farimani, Designing a

Model of key Stakeholders'

Expectations in the Subway

Construction Projects: Studied in

MUR Construction Project, 2018)

Vuorinen and Martinsuo (2018)

(Vuorinen \& Martinsuo, 2018)

Derakhshan et al. (2019) (Derakhshan,

Turner, \& Mancini, 2019)

Bahadorestani et al. (2019)

(Bahadorestani, Naderpajouh, \&

Sadiq, Planning for sustainable

stakeholder engagement based on the

assessment of conflicting interests in

projects , 2019)

Yu et al. (2019) (Yu, Liang, Shen, Shi,

\& Wang, 2019)

studying the effect of portfolio-internal stakeholders on project portfolio success

examination background the project success and stakeholders of projects

Baqeria et al. (2019) (Baqeria,

Mohammadia, \& Mofrad Gilania, A multi-objective model for selecting the project portfolio 2019)

a framework to identify project stakeholders and to determine the expectations of key stakeholders

studying the influence of stakeholders on projects

Reviewing literature of project governance and roles of stakeholders

Conflict management between the project stakeholder

An optimization model for analyzing stakeholder conflicts in urban projects 


\section{Methodology and the research steps}

The research steps are as follow:

Phase 1: the stakeholders' university analysis

- $\quad$ Step 1. Identifying stakeholders

- Step 2. Classifying Stakeholders

- Step 3. Identifying key stakeholder requirements (Chapleo \& Sims, 2010) (Mainardes, Alves, \& Raposo, 2013) (Soleimanpour \& Zehtabchian, 2009)

Phase 2: the stakeholders' university analysis

Model description

- Step 4. Identifying variables and parameters

- Step 5. Identifying the objective function

- Step 6. Identifying the constraints

- Step 7: Formulate the mathematical model

- Step 8: Solving the model and the result analysis

Fig. 1 shows the two phases and related steps.

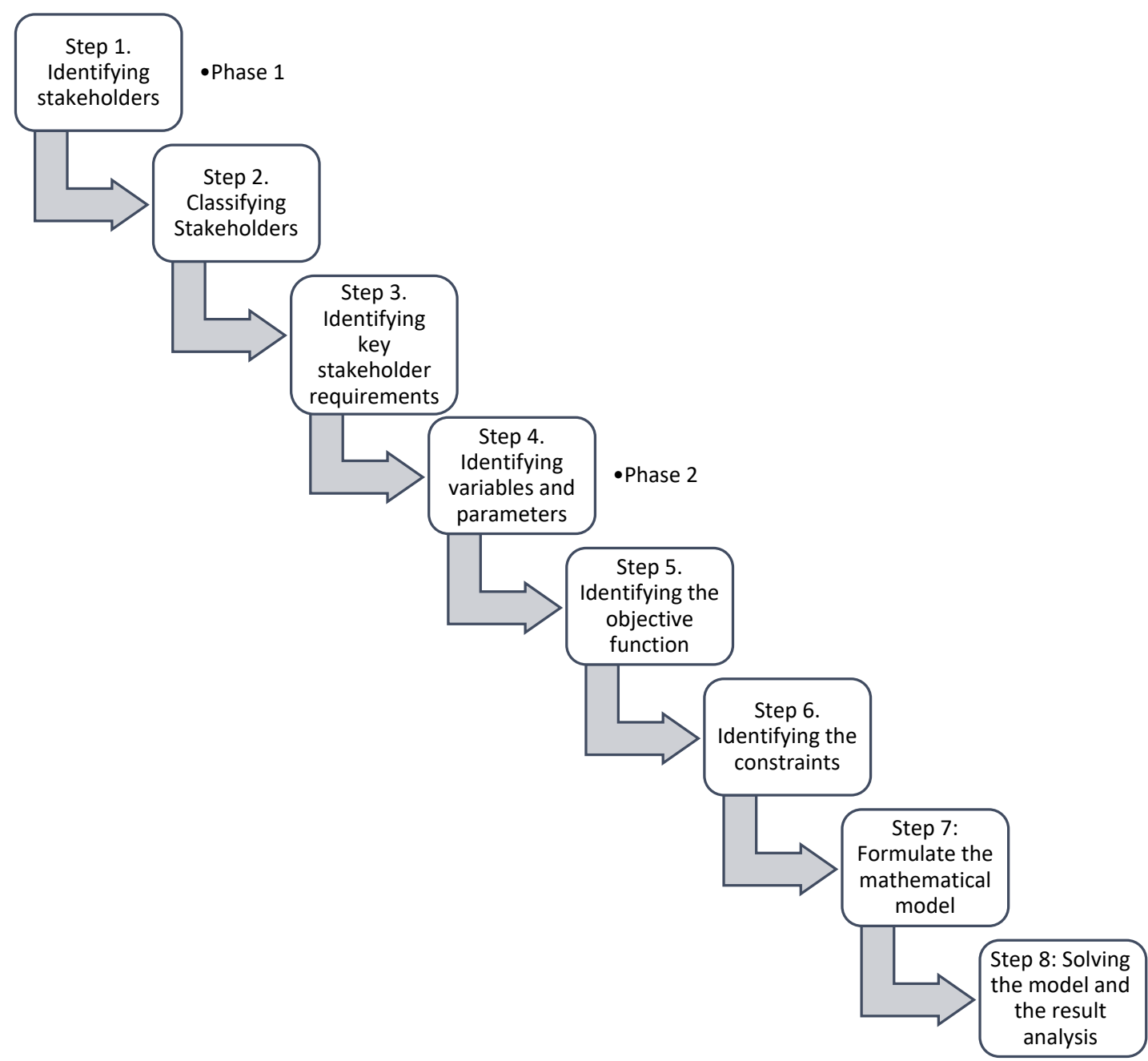

Fig. 1. Two main phases and research steps of the research 


\subsection{Stakeholder identification}

Similar lists of universities stakeholders as well as brainstorming were used by some experts of university under study to identify stakeholders. These experts included a number of faculty members, researchers, university administrators and staff. The experts mentioned have assisted the project team in gathering information and analyzing the problem. Following similar cases and examining the status of the university under study, the university stakeholders were listed as follows:

- Faculty Members

- Researchers

- Staff

- Students

- Board of trustees

- Ministry of Science, Research and Technology

- Companies

- Scientific associations and research centers (such as science and research towns, science and technology parks, knowledge-based companies, etc.)

- People (neighbors)

- Short course applicants

- Other universities

- Public interest groups (Water, Electricity and Gas departments, Municipality, ...)

Table 2 shows the university stakeholders in two (2) external and internal stakeholders.

\section{Table 2}

The stakeholders of the University under study

\begin{tabular}{|c|c|}
\hline Internal stakeholders & External stakeholders \\
\hline $\begin{array}{ll}\text { - } & \text { Faculty Members } \\
\text { - } & \text { Researchers } \\
\text { - } & \text { Staff } \\
\text { - } & \text { Students } \\
\text { - } & \text { Board of trustees }\end{array}$ & $\begin{array}{ll}\text { - } & \text { Ministry of Science, Research and Technology } \\
\text { - } & \text { Companies } \\
\text { - } & \text { Scientific associations and research centers } \\
\text { - } & \text { Neighbors } \\
\text { - } & \text { Othort course applicants } \\
\text { - } & \text { Public interest groups }\end{array}$ \\
\hline
\end{tabular}

\subsection{Stakeholder power/interest analysis}

One of the most well-known stakeholder management tools is the power/interest matrix (Johnson, Scholes, \& Whittington, 2008). This method was originally invented by Mendelow and completed by Johnson and Scholes. The power-interest matrix analyzes the following dimensions:

- The interest of each stakeholder group that expresses their expectations of the organization / project decisions

- The power of each stakeholder that expresses their ability to influence

Stakeholder positioning in the power-interest matrix is judged on a scale of zero to 10, given their relative power and their degree of interest in imposing expectations. Stakeholders are classified into four groups and the strategy of interaction with each is determined.

\begin{tabular}{c|c|c|}
\hline High & $\begin{array}{c}\text { High power, Low interest } \\
\text { Power }\end{array}$ & $\begin{array}{r}\text { Key stakeholders } \\
\bullet \quad \text { Keep Satisfied }\end{array}$ \\
\cline { 2 - 3 } Low & $\begin{array}{r}\text { Low power, Low interest } \\
\text { • Minimum Effort }\end{array}$ & Low power, High Interest \\
& \multicolumn{2}{|c}{ Keep Informed } \\
\hline & Low & \\
\hline
\end{tabular}

Fig. 2. Stakeholder classification and related strategies in the Power/Interest matrix (Johnson, Scholes, \& Whittington, 2008) 
The two criteria of power and interest in this article are defined as follows:

- Power: the ability to influence internal or external stakeholders according to reasons such as status, specialty and resource

- Interest: pursuit of the results of the organization with regard to matters such as economic interests, legal rights, maintaining the current situation, obtaining socio-political status, etc.

Table 3

Scores of power and interest for the university stakeholders

\begin{tabular}{|c|c|c|c|c|c|c|c|c|c|c|c|}
\hline & & \multicolumn{5}{|c|}{ Power } & \multicolumn{5}{|c|}{ Interest } \\
\hline & & Very high & High & Medium & Low & $\begin{array}{l}\begin{array}{l}\text { Very } \\
\text { low }\end{array} \\
\text {. }\end{array}$ & 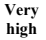 & High & Medium & Low & Very low \\
\hline & & 5 & 4 & 3 & 2 & 1 & 5 & 4 & 3 & 2 & 1 \\
\hline \multirow{5}{*}{ 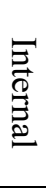 } & Faculty Member & $\sqrt{ }$ & & & & & & $\sqrt{ }$ & & & \\
\hline & Researchers & & $\sqrt{ }$ & & & & $\sqrt{ }$ & & & & \\
\hline & Staff & & & & $\sqrt{ }$ & & $\sqrt{ }$ & & & & \\
\hline & Students & & & $\sqrt{ }$ & & & $\sqrt{ }$ & & & & \\
\hline & Board of trustees & $\sqrt{ }$ & & & & & $\sqrt{ }$ & & & & \\
\hline \multirow{7}{*}{ 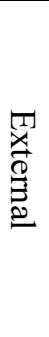 } & $\begin{array}{l}\text { Ministry of Science, Research } \\
\text { and Technology }\end{array}$ & $\sqrt{ }$ & & & & & & $\sqrt{ }$ & & & \\
\hline & Companies and Industries & & $\sqrt{ }$ & & & & & & & $\sqrt{ }$ & \\
\hline & $\begin{array}{l}\text { Scientific associations and re- } \\
\text { search centers }\end{array}$ & & & & $\sqrt{ }$ & & $\sqrt{ }$ & & & & \\
\hline & Neighbors & & & & $\sqrt{ }$ & & & & & $\sqrt{ }$ & \\
\hline & Short course applicants & & & & $\sqrt{ }$ & & & & & $\sqrt{ }$ & \\
\hline & Other universities & & & & $\sqrt{ }$ & & & $\sqrt{ }$ & & & \\
\hline & Public interest groups & & $\sqrt{ }$ & & & & & & & $\sqrt{ }$ & \\
\hline
\end{tabular}

According to scoring, stakeholder positioning is performed in the power-interest matrix. The invention of this matrix is referred to Mendelow, and hence it is also known as the Mendelow's Matrix (Walters \& Kitchin, 2009).

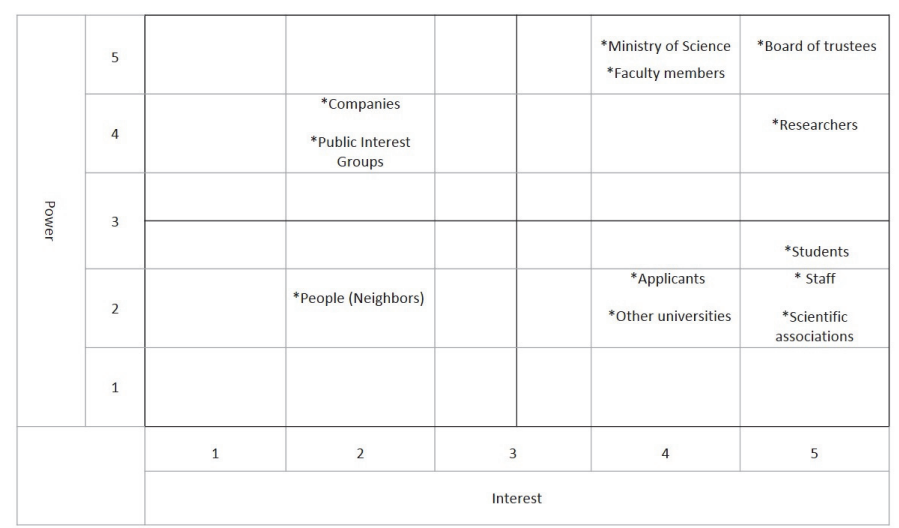

Fig. 3. Positioning of university stakeholders on the power-interest matrix

The classification of the university stakeholders based on the interest-power matrix will be as follows:

First category: the stakeholders with High power - High interest

These stakeholders, also known as main or key stakeholders, or key actors include:

- Board of trustees

- Faculty members

- Researchers

- Ministry of Science, Research and Technology 
Second Category: the stakeholders with High power - Low Interest

The following stakeholders are considered:

- Companies

- Public Interest Groups

Third category: the stakeholders with Low power - High interest

Stakeholders in the third category include:

- Students

- Applicants

- Staff

- Scientific associations and research centers

- Other universities

Fourth category: the stakeholders with Low power - Low interest

These stakeholders, called minor stakeholders, include People (Neighbors).

The following figure shows the categorization of university stakeholders into four quadrants of the power-interest matrix.

\section{Key stakeholders' expectations and requirements}

At the university under study, the aim is to arrange a portfolio of research and educational projects. For this university, both the teaching and research missions are important, and not just the educational mission. Now, given the needs and expectations of key stakeholders, it is necessary to adjust the portfolio of colleges' educational and research projects. The goal is to determine the portfolio of each college's research, educational and training projects (and activities) to maximize the benefits of the projects' portfolio. To accomplish this goal, a mathematical model has been developed. For the next steps of the research, it is necessary to consider the expectations and needs of key stakeholders. In this study, we focus only on portfolio project requirements and expectations, such as expectation to earning income, capacity constraints (person-hours), cost of research projects by faculty and researchers, and minimum and maximum student acceptance capacity. These expectations and requirements are as follows:

- The Board of Trustees has obliged the manager of the College to earn income as much as possible. Of course, some college expenses will be offset by the board of trustees.

- The Ministry of Science obliges the College not to exceed the number of students admitted each year. Also, for this, a minimum number is set.

- The annual capacity (person-hours) of faculty and researchers for research, educational and training projects is limited.

- The cost of conducting research projects by faculty and researchers varies.

The following table shows these expectations and needs of key stakeholders.

Table 4

Four key stakeholders' expectations and requirements

\begin{tabular}{|c|c|c|c|c|}
\hline $\begin{array}{l}\text { Expectations/Requirements } \\
\text { stakeholder }\end{array}$ & Revenue & Cost & $\begin{array}{c}\text { Time / capacity } \\
\text { constraint }\end{array}$ & $\begin{array}{c}\text { Number of } \\
\text { students }\end{array}$ \\
\hline Board of trustees & $*$ & -- & --- & --- \\
\hline Ministry of Science, Research and Technology & --- & -- & -- & $*$ \\
\hline Faculty Members & --- & $*$ & $*$ & --- \\
\hline Researchers & --- & $*$ & $*$ & --- \\
\hline
\end{tabular}


The main purpose of this mathematical model is to maximize the benefit of the College's research and training projects. In addition, constraints related to the expectations and requirements of key stakeholders should be considered. The assumptions of the proposed mathematical model are as follows:

- The cost of doing all the projects is the same as their income.

- The capacity of faculties and researchers to conduct projects and activities is limited.

- The Ministry of Science will pay a fee to the college annually for each student.

- College students are admitted to the Master of Science (M.Sc.) only, and each student is assigned to a faculty member as a supervisor.

- Only one person will conduct each research project.

- The cost of doing a research project by a faculty member and researcher varies. This concerns the per-hour pay gap between faculties and researchers.

\section{Identifying variables and parameters}

The parameters of this model are as follows:

\begin{tabular}{cl}
$\mathrm{R}_{\mathrm{nd}}$ & Incomes from any research project \\
$\mathrm{C}_{\mathrm{nd}-\mathrm{fa}}$ & The cost of conducting each research project by a faculty member \\
$\mathrm{C}_{\mathrm{nd}-\mathrm{re}}$ & The cost of any research project by researchers \\
$\mathrm{C}_{\mathrm{s}}$ & Annual costs per student \\
$\mathrm{R}_{\mathrm{s}}$ & Annual income of each student (paid by Ministry of Science) \\
$\mathrm{C}_{\mathrm{stc}}$ & The cost of running any short term \\
$\mathrm{R}_{\mathrm{stc}}$ & Income from running any short term \\
$\mathrm{PNC}_{\mathrm{fa}}$ & Person-hours per year required for each research project by each faculty member \\
$\mathrm{PNC}_{\mathrm{re}}$ & Person-hours per year required for each research project by each researcher \\
$\mathrm{SNC}_{\mathrm{fa}}$ & Person-hour required annually for each student by each faculty member \\
$\mathrm{STC}_{\mathrm{fa}}$ & Person-hours required annually to participate in a short course run by each faculty \\
& member \\
$\mathrm{STC}_{\mathrm{re}}$ & Person-hour required annually to participate in the implementation of a short-term \\
$\mathrm{N}_{\mathrm{fa}}$ & course by each researcher \\
$\mathrm{N}_{\mathrm{re}}$ & Number of faculty members \\
$\mathrm{TH}_{\mathrm{fa}}$ & Number of researchers \\
$\mathrm{TH}_{\mathrm{re}}$ & Total person-hours per year per faculty member \\
$\propto$ & Total person-hours per year per researcher \\
$\beta$ & Minimum number of students admitted (Ministry of Science Restrictions) \\
$\theta$ & Maximum number of students admitted (Ministry of Science Restrictions) \\
\hline
\end{tabular}

The variables of proposed model are as follows:

$\begin{array}{ll}\mathrm{X}_{\mathrm{nd}-\mathrm{fa}} & \text { Number of research projects to be carried out by faculty members } \\ \mathrm{X}_{\mathrm{nd}-\mathrm{re}} & \text { Number of research projects to be carried out by researchers } \\ \mathrm{X}_{\mathrm{s}} & \text { Number of eligible students per year } \\ \mathrm{X}_{\mathrm{stc}} & \text { Number of short-term courses per year }\end{array}$

\section{Identifying the objective function}

The objective function of the model is to maximize the total annual profits of the college by taking into account the difference between the incomes and costs of doing research projects, the annual student acceptance, and the implementation of short-term courses. Based on the combination of parameters and variables, the objective function can be written as follows:

$$
\max \left(R_{n d}-C_{n d-f a}\right) \cdot X_{n d-f a}+\left(R_{n d}-C_{n d-r e}\right) \cdot X_{n d-r e}+\left(R_{s}-C_{s}\right) \cdot X_{s}+\left(R_{\text {stc }}-C_{s t c}\right) \cdot X_{\text {stc }}
$$




\section{Identifying the constraints}

The model limitations include:

- The first constraint is the capacity limitation (annual person-hours) of faculty members to undertake research projects, annual student admissions, and short-term courses. This restriction can be displayed as follows:

$\mathrm{PNC}_{\mathrm{fa}} \cdot \mathrm{X}_{\mathrm{nd}-\mathrm{fa}}+\mathrm{SNC}_{\mathrm{fa}} \cdot \mathrm{X}_{\mathrm{s}}+\mathrm{STC}_{\mathrm{fa}} \cdot \mathrm{X}_{\mathrm{stc}} \leq \mathrm{TH}_{\mathrm{fa}} \cdot \mathrm{N}_{\mathrm{fa}}$

- The next constraint is the capacity limitation (annual person-hours) of researchers to undertake research projects and to run short-term courses. This restriction is written as follows:

$\mathrm{PNC}_{\text {re }} \cdot \mathrm{X}_{\text {nd-re }}+\mathrm{STC}_{\mathrm{re}} \cdot \mathrm{X}_{\text {stc }} \leq \mathrm{TH}_{\mathrm{re}} \cdot \mathrm{N}_{\text {re }}$

- Other constraints are the minimum and maximum number of students admitted annually by the Ministry of Science. These two constraints are illustrated by the following equations:

$\propto \leq \mathrm{X}_{\mathrm{s}}$

$\mathrm{X}_{\mathrm{s}} \leq \beta$

- The last constraint is the requirement for colleges to run a minimum number of short-term courses per year. This restriction is obligated by the Board of Trustees (the following formula):

$\mathrm{X}_{\text {stc }} \geq \theta$

\section{Formulating the mathematical model}

Finally, putting together the objective function and the constraints, the proposed mathematical model will be as follows:

$\max \left(R_{n d}-C_{n d-f a}\right) \cdot X_{n d-f a}+\left(R_{n d}-C_{n d-r e}\right) \cdot X_{n d-r e}+\left(R_{s}-C_{s}\right) \cdot X_{s}+\left(R_{\text {stc }}-C_{s t c}\right) \cdot X_{\text {stc }}$

subject to

$$
\begin{aligned}
& \mathrm{PNC}_{\mathrm{fa}} \cdot \mathrm{X}_{\mathrm{nd}-\mathrm{fa}}+\mathrm{SNC}_{\mathrm{fa}} \cdot \mathrm{X}_{\mathrm{s}}+\mathrm{STC}_{\mathrm{fa}} \cdot \mathrm{X}_{\mathrm{stc}} \leq \mathrm{TH}_{\mathrm{fa}} \cdot \mathrm{N}_{\mathrm{fa}} \\
& \mathrm{PNC}_{\mathrm{re}} \cdot \mathrm{X}_{\mathrm{nd}-\mathrm{re}}+\mathrm{STC}_{\mathrm{re}} \cdot \mathrm{X}_{\mathrm{stc}} \leq \mathrm{TH}_{\mathrm{re}} \cdot \mathrm{N}_{\mathrm{re}} \\
& \propto \leq \mathrm{X}_{\mathrm{s}} \leq \beta \\
& \mathrm{X}_{\text {stc }} \geq \theta \\
& \mathrm{X}_{\mathrm{nd}}, \mathrm{X}_{\mathrm{s}}, \mathrm{X}_{\mathrm{stc}} \geq 0
\end{aligned}
$$

Solving the model and the results analysis

The proposed mathematical model, based on current college information, is solved by Lingo soft-

\begin{tabular}{|c|c|c|c|c|c|c|c|c|c|}
\hline $\mathrm{R}_{\mathrm{nd}}$ & $\mathrm{C}_{\mathrm{nd}-\mathrm{fa}}$ & $\mathrm{C}_{\mathrm{nd}-\mathrm{re}}$ & $\mathrm{C}_{\mathrm{s}}$ & $\mathrm{R}_{\mathrm{s}}$ & $\mathrm{C}_{\mathrm{stc}}$ & $\mathrm{R}_{\mathrm{stc}}$ & $\mathrm{TH}_{\mathrm{fa}}$ & $\propto$ & 10 \\
\hline 20 & 16 & 13 & 2 & 4 & 20 & 16 & 1150 & & \\
\hline & & & & & & & & $\beta$ & 20 \\
\hline $\mathrm{PNC}_{\mathrm{fa}}$ & $\mathrm{PNC}_{\mathrm{re}}$ & $\mathrm{SNC}_{\mathrm{fa}}$ & $\mathrm{STC}_{\mathrm{fa}}$ & STC $_{\text {re }}$ & $\mathrm{N}_{\mathrm{fa}}$ & $\mathrm{N}_{\mathrm{re}}$ & $\mathrm{TH}_{\mathrm{re}}$ & & \\
\hline 300 & 300 & 150 & 150 & 150 & 5 & 10 & 1000 & $\theta$ & 2 \\
\hline
\end{tabular}
ware (version 14). The following table shows the values of the parameters and the results of the solution and the amount of decision variables.

Table 5

The information of the parameters 
Table 6

The results of solving the model by Lingo software

\begin{tabular}{ccc}
\hline Variable & Value \\
\hline X-NDFA & 11 \\
X-NDRE & 37 \\
XS & 10 \\
XSTC & Objective value: & 332.0000 \\
\hline
\end{tabular}

Global optimal solution found

The model solution results show how to maximize college profit (expecting trustees as a key stakeholder) and, of course, in line with the constraints of three other key stakeholders (faculty members, researchers and the Ministry of Science):

- College researchers must do 37 research projects

- Faculty members need to do 11 research projects

- Admitted students must be ten (10)

- Two short ime courses are required

As can be seen from the results, because of the increased benefits of doing research projects, the proposed mathematical model allocates a large part of the capacity of faculty and researchers to research projects and the number of students admitted and the proposed short-term courses are set to the minimal level based on compliance.

\section{Conclusions}

In this paper, a mathematical model has been developed to simultaneously address the expectations and the requirements of four key stakeholders, with the help of this model, while expecting the board of trustees to be a key stakeholder and maximizing college profit. In order to manage the conflicts between key stakeholders, it is necessary to respect the constraints of other key stakeholders (faculty members, researchers and the Ministry of Science) so that their satisfaction is as much as possible. Based on the results of the mathematical model, the faculty administrator cannot expect to run a large number of research projects and short-term courses simultaneously, as well as to accommodate a significant number of students, regardless of the capacity limit (person-hours) of their faculty and researchers. The results of this study can help university managers make decisions and create strategic plans. Another important point is that this study should be repeated every few years as the conditions, requirements and expectations of the university stakeholders may change.

\section{References}

Bahadorestani, A., Ghalehnovi, M., \& Motahari Farimani, N. (2018). Designing a Model of key Stakeholders' Expectations in the Subway Construction Projects: Studied in MUR Construction Project. Amirkabir Journal of Civil Engineering, 50(1), 67-70.

Bahadorestani, A., Naderpajouh, N., \& Sadiq, R. (2019). Planning for sustainable stakeholder engagement based on the assessment of conflicting interests in projects . Journal of Cleaner Production.

Baqeria, K., Mohammadia, E., \& Mofrad Gilania, M. (2019). Multi objective project portfolio selection. Journal of Project Management, 4(4), 249-256.

Bazyar, M., Rashidian, A., Alipouri Sakha, M., Doshmangir, L., Rahimi, N., Ranjbar, M., . . Olyaeemanes, A. (2018). Stakeholders analysis of merging social health insurance funds in Iran: what kind of interests they may gain or lose? International Journal Health Planning Management, 1-20.

Beringer, C., Jonas, D., \& Kock., A. (2013). Behavior of internal stakeholders in project portfolio management and its impact on success. International Journal of Project Management, 31, 830-846.

Chapleo, C., \& Sims, C. (2010). A Framework for Stakeholder Analysis in Higher Education (A Case Study of the University of Portsmouth. Perspectives.

Davis, K. (2014). Different stakeholder groups and their perceptions of project success. . International Journal of Project Management, 32, 189-201.

Derakhshan, R., Turner, R., \& Mancini, M. (2019). Project governance and stakeholders: a literature review. International Journal of Project Management, 37, 98 - 116. 
Eskerod, P., \& Larsen, T. (2018). Advancing project stakeholder analysis by the concept 'shadows of the context. International Journal of Project Management, pp. 161-169.

Fleaca, E., Fleaca, B., \& Maiduc, S. (2017). modeling stakeholders relationships to strengthen the entrepreneurial behavior of higher education institutions. Procedia Engineering, 935 - 942.

Freeman, R. (1984 (First Published by Pitman)- 2010 (Digital Version by Cambridge University Press)). Strategic Management: A stakeholder Approach. Boston: Pitman- Cambridge University Press).

Friedman, A., \& Miles, S. (2006). Stakeholders : Theory and Practice. Oxford University Press.

Hujainah, F., Abu Bakar, R., Al-Haimi, B., \& Abdulgabber, M. (2017). Stakeholder Quantification and Prioritisation Research: A Systematic Literature Review. Information and Software Technology, PP. 8599.

Johnson, G., Scholes, K., \& Whittington, R. (2008). Exploring Corporate Strategy. Financial Times/Prentice Hall.

Kettunen, J. (2014). The Stakeholder Map in Higher Education. turku university of applied sciences.

Kumar, S. (2015). Modeling and Managing Stakeholder's Power and Influence for Quality Improvement in Construction Projects - A Case Study at Jaipur Metro. Int. Journal of Civil Engineering, 2.

Mainardes, E., Alves, H., \& Raposo, M. (2013). Identifying Stakeholders in a Portuguese university: a case study. Revista de Educación.

Matkovic, P., Tumbas, P., Sakal, M., \& Pavlićević, V. (2014). University stakeholders in the analysis phase of curriculum development process model. ICERI2014 Conference. Seville, Spain.

Meo, I. D., Cantiani, M. G., Ferretti, F., \& Paletto, A. (2018). Qualitative Assessment of Forest Ecosystem Services: The Stakeholders' Point of View in Support of Landscape Planning. MDPI-Forests.

Mitchell, R., Agle, B., \& Wood, D. (1997). Toward a Theory of Stakeholder Identification and Salience: Defining the Principle of Who and What Really Counts.

Pereira, B., Senna,, L., \& Lindau, L. (2018). Stakeholder Value Network: Modeling key relationships for advancing towards high quality bus transit systems. Research in Transportation Economics, 69(C), pp. 386-393.

Public university. (2019). (Wikipedia, the free encyclopedia) Retrieved from https://en.wikipedia.org

Qingchun, Y. (2017). A Study of Crisis Management Based on Stakeholders Analysis Model. Earth and Environmental Science.

Sharp, H., Finkelstein, A., \& Galal, G. (1999). Stakeholder Identification in the Requirements Engineering Process. 10th International Workshop on Database \& Expert Systems Applications (DEXA) (pp. pp. 387391). IEEE Computer Society Press.

Soh, C., Chua, C., \& Singh, H. (2011). Managing diverse stakeholders in enterprise systems projects: a control portfolio approach. Journal of Information Technology, 26, 16-31.

Soleimanpour, H., \& Zehtabchian, R. (2009). Stakeholder analysis of Mashhad House Manufacturing Factory. Master thesis: University of Borås.

TETŘEVOVÁ, L., \& SABOLOVÁ, V. (2017). University Stakeholder Management. International conference on education and educational technologies.

Tran, L. (2018). Game of blames: Higher education stakeholders' perceptions of causes of Vietnamese graduates' skills gap. International Journal of Educational Development, 302-312.

Vuorinen, L., \& Martinsuo, M. (2018). Value-oriented stakeholder influence on infrastructure projects. International Journal of Project Management.

Walters, G., \& Kitchin, P. J. (2009). Stakeholder Management and Sport Facilities: A Case Study of the Emirates Stadium. European Association of Sport Management. Amsterdam.

Wang, H.-M., \& Sengupta, S. (2016). Stakeholder relationships, brand equity, firm performance: A resourcebased perspective. Journal of Business Research, pp. 5561-5568.

$\mathrm{Wu}, \mathrm{X}$. (2007). Stakeholder identifying and positioning (SIP) models: from Google's operation in China to general case analysis framework. Public Relations Review, Vol. 33, pp. 415-425.

Yu, T., Liang, X., Shen, G., Shi, Q., \& Wang, G. (2019). An optimization model for managing stakeholder conflicts in urban redevelopment projects in China. Journal of Cleaner Production, 212, 537-547.

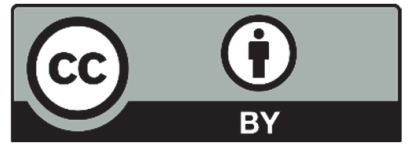

(C) 2020 by the authors; licensee Growing Science, Canada. This is an open access article distributed under the terms and conditions of the Creative Commons Attribution (CC-BY) license (http://creativecommons.org/licenses/by/4.0/). 